\title{
Melissopalynological determination of the Pollen density, Botanical origin and Ogiek Honey types in Eastern Mau Forest, Kenya
}

\author{
Philip Onyango \\ Department of Botany, School of Physical and Biological Sciences \\ Maseno University, Kisumu City
}

Kenya

\begin{abstract}
The current international market demands for the set up of honey quality control protocols according to the botanical origin based on pollen content. The objective of the present study was to determine the pollen density, honey types, and botanical origin of honey from the Eastern Mau Ogiek beekeepers as a reference to commercial strategies for sellers and buyers. 27 honey samples, three from each of the strata (Mariashoni, Kapkembu, and Nessuit) were collected at the end of April, 2016; August 2016; December, 2016 from the hives of Beekeeping Ogieks in Eastern Mau forest region. $10 \mathrm{~g}$ of the honey samples were processed through approved melissopalynological procedures. Absolute pollen counts ranged from 47,898-160,200/10g. 59.3\% and $40.7 \%$ of honey samples fell into classes II and III respectively with no representations of Classes I, IV and V. 29.63\% of the honey samples were unifloral, while the rest constituted heterofloral honey. Unifloral honey samples were observed from the three mesoregions of Eastern Mau forest. 50\% of the unifloral honey were collected in April (2016). Botanical origin from predominant pollen types were Acacia type, Eucalyptus type, Croton spp. type, Albizia coriaria type, Cordia abyssinica type, and Vernonia auriculifera type. The extent of predominance ranged from (47.1\%-66.40\%), there was bifloral honey observed in MA-S1-DE sample (Vernonia auriculifera type and Croton spp. type, $46.0 \%$ and $47.50 \%$ respectively). Secondary pollen ranged from (16.4\%-43.4\%). All honey samples were floral honey.
\end{abstract}

Key Words: Melissopalynology, Botanical origin, Mau forest, honey, Ogieks.

\section{INTRODUCTION}

Melissopalynology is the pollen analysis of honey to determine its type, quality, and origin. Melissopalynology is an applied branch of palynology (Attri, 2010). It is one of the most important ways of determining the Botanical origin of honey apart from the physicochemical analysis and organoleptic or sensory analysis. Melissopalynology is also referred to as melittopalynology. 'Melissopalynology' is from the Greek words Melissa meaning bee and honey (Salonen and Julkunen-Tiito, 2012). The study of pollen in Honey dates as far back as the nineteenth century. Since this period, several workers have examined the pollen contents of various Swiss, French, American, India and other European honey samples (Igbe and Obasanmi, 2014). There are proposals to develop honey cooperatives . Ogieks mainstay is in Mariashoni forest. Most of the honey in Kenyan market is adulturated .Ogiek honeys have found ways into supermarkets in Europe (Hansard, 2016 ).

Melissopalynology is the primary standard and official test used to determine both the botanical and geographical origin of honey (Akratanakul, 1990) as well as development of pollen analytical standards, which contribute to quality control and value addition to honey for export market. This in turn limits honey fraud (Louveaux et al., 1978). Because of trade agreements, import tariffs and restrictions, most of the leading honey producing nations require labeling of honey before it is sold. With the use of the marker pollen in honey, melissopalynology is able to effectively judge the nature of the mixing of the native honey and exotic honey (Bryant, 2001, Luis et al., 2015). The occurrence of pollen grains in honey can be attributed to their presence in the floral nectar or exogenous sources (Salonen et al., 2009). Honey pollen profile reflects forest vegetation diversity and species composition of the plants foraged by honey bees. The relative pollen frequency is used in labelling of honey geographical origin, a factor that significantly influences honey's commercial value. The pollen profile is also used as a traceability tool by food control institutions (Corvucci et al., 2015). The European Standard Directive 110/01, defines honey as unifloral when it is from a completely or partially botanical origin including its pollen corresponding to their origin (Ciapinni et al., 2013; Bryant, 2001). The pollen from the combination of wind and insect-pollinated taxa found in a honey sample will often produce a pollen spectrum that is unique for the specific geographical region where it was produced (Igbe and Obasanmi, 2014). In general, melissopalynological 
studies used random sampling because the main concern is determining the floral origin, purity and broad geographic origins of honey, which do not require long term monitoring (Ponnuchamy et al., 2014).

Identifying pollen returned to the hive provides a direct measure of pollen foraging, whilst the pollen within honey provides a longer term overview of plants being used for both nectar and pollen (Kirk and Howes, 2012). These methods are typically used to identify the botanical composition of honey in order to check its geographic origin for food quality and traceability purposes. They have more rarely been used to investigate foraging preferences (Hawkins et al., 2015). The main honey producing countries require accurate labelling of honey before commercialisation, including floral classification, traditionally achieved by melissopalynology (Luis et al., 2015). The occurrence of pollen grains in honey can be explained either by their presence in the floral nectar or due to exogenous sources (Salonen at al., 2009). Honey pollen profile reflects forest vegetation, floral diversity and species composition of the plants foraged by honey bees. The relative pollen frequency is used for label purposes and to guarantee the geographical origin, factors that greatly influence honey's commercial value, being also used as a traceability tool by food control institutions (Corvucci et al., 2015). The European Standard Directive 110/01, defines honey as unifloral when it is from a completely or partially botanical origin including its pollen, physicochemical and sensory characteristics corresponding to their origin. Consequently, the three analytical systems are complementary assays to honey characterisation (Ciapinni et al., 2013).

The knowledege achieved through melissopalynology, bee botany and nectar plants helps in beekeeping potential areas to provide better honey production and to improve pollination services. Large horticultural undertakings may not flourish in the long run without large scale scientific bee keeping (Singh and Chaturvedi, 2017). Melissopalynology has been extensively used to determine the purity, geographical and floral origins of honey as well as assessing honey correlations with in situ climatic parameters such as rainfall and temperature which are important in the context of external factors influencing pollinators and pollination networks (Nascimento and Nascimento, 2012; Ponnuchamy et al., 2014). Through melissopalynology, it is also possible to determine if a sample of honey is adulterated or is of botanical origin. It is also possible to determine if the honey sample is poisonous or totally fit for consumption by human beings as some honey samples could be poisonous to children or people with certain diseases. Pollen grains are the essential tools in the analysis of honey. Different types of pollen are used to indicate floral nectar sources utilized by bees to produce honey. Relative pollen frequency is often used to verify and label a honey sample as to the major and minor nectar sources. This information has important commercial value because honey made from some plants commands a premium price. Even non premium grades of honey require certain types of verification because they must be correctly labelled before they are marketed. Identifying and quantifying the pollen in honey samples is one of the best ways to determine the range of nectar types used to produce honey, and therefore label correctly, based on actual foraging resources. The pollen from the combination of wind and insect-pollinated taxa found in a honey sample will often produce a pollen spectrum that is unique for the specific geographical region where it was produced (Igbe and Obasanmi, 2014).

Numerous studies have demonstrated the economic value of honeybees to the agricultural industry of the world especially areas in south of Sahara, this phenomenon is not fully known because of the lack of scientific studies (Schweitzer, 2013)._Blossom honey c omes from plant nectar; is also referred to as nectar honey. Honeydew Honey is obtained mainly from excretions of plant sucking insects (Hemiptera) on the living parts of plants or secretions of living parts of plants. Monofloral honey is results from bees fora ging predominantly on one type of plant, and is named according to that plant. Common monofloral honey types are Clover, Acac $i a$, and sunflower honey. Monofloral honey is priced more highly than polyfloral honey. Light, monofloral honeys like orange blo ssom or Acacia always obtain higher prices than blends of honeys because they look so attractive. Multifloral honey (also known as polyfloral) has several botanical sources, none of which is predominant, for example, meadow blossom honey, and forest hone y (Codex Alimentarius, 2001; COMESA/FDHS 002, 2004). Honey is marketed as either generic (large volume by Apis mellifera) or specialty honey which could be unifloral, come from particular region, has substantial health benefits, meets consumer purchas e criteria (organic, fair trade) or sustainably produced assisting on conservation efforts. Manuka Honey from New Zealand is a spe cialty honey billed as one of the most expensive honey. Other specialty honeys have been marketed in the auspices of international gorilla conservation in Uganda and Rwanda. Africa honey sold as generic blend is unlikely to compete with honey from major exp orting countries like China and Argentina (Stubbs, 2011). Honey production is the driving force behind bee keeping (Alaazi et al, 2010). Beekeeping sustains natural resources and practiced by communities as a source of income and livelihood due to its low sta rt up costs (Bradbear, 2009; Wilfredo et al., 2010). Overexploitation of the forest is driven by extreme poverty of forest neighbori ng communities. Conservation programs through beekeeping extend benefits to communities and enable their entry into the mains tream economies. Involvement of communities through beekeeping is a stakeholder centered forest management practise that foste rs acceptance and participation compared to the top down approach that has been practiced in the past (Barbara and Jurgen, 2009). To ensure beekeeping benefits the community and subsequently forest conservation, an enhanced product quality and efficient ma rket linkages to incentivize participating communities is necessary (Hausser, 2002). Challenges to full exploitation of bee keeping in biodiversity conservation and community empowerment include lack of enabling regulatory and policy framework lack of stand ards and poor quality of honey, lack of an entrepreneurial and business approach to beekeeping, honey production and marketing (Alaazi et al, 2010).

\section{METHOD}

Sample collection and preparation: Three honey samples were collected from each of strata (Mariashoni, Kapkembu, and Nessuit) at the end of April, 2016; August 2016; December, 2016) from the hives of Bee keeping Ogieks of the Eastern Mau forest region. Only the honey strained by fine sieves or cheese-cloth were collected from the beekeepers, placed in sealed food grade screw cup bottles, and transported to the laboratory in cooler boxes. Samples from 3 beekeepers (three replicates) per 
population substratum were collected. Samples for further analysis were refrigerated at $3 \pm 2{ }^{0} \mathrm{C}$ and stored in dark with screw cup bottles. Laboratory sample consisted of 100-200 g of honey. The laboratory sample was transformed into the test sample by thorough stirring. Granulated hard samples were softened by slight warming. Dirty samples were liquefied at $40^{\circ} \mathrm{C}$ and strained through cheese-cloth. Slides were prepared from $10.0 \mathrm{~g}$ of honey weighed and dissolved in $20 \mathrm{ml}$ of hot distilled water at $39^{\circ} \mathrm{C}$. The solution was then centrifuged for $10 \mathrm{~min}$ at $2500 \mathrm{r} / \mathrm{min}$ and decanted. The honey sugars was completely removed by dispersing again with $10 \mathrm{ml}$ of distilled water. The solution was then poured into a centrifuge tube, and centrifuged for 5 min. The entire sediment was put on a slide using Pasteur pipettes and spread out over an area about 20 X $20 \mathrm{~mm}$, using a thin glass. After drying by slight heating at $40^{\circ} \mathrm{C}$, the sediment was mounted with glycerine jelly, liquefied by heating in a water-bath at $40^{\circ} \mathrm{C}$. The sediment constituents remaining in the tube were stirred again with a drop of distilled water, pipetted again, and the used pipette rejected to eliminate the contamination of pollens from other honeys. If the honey sample is poor in pollen $20 \mathrm{~g}$ was used. For samples rich in sediment, the residuum was spread under two cover glasses. The microscopical identification was based on the identification and counting of pollen grains and other particles in honey. Identification was done by reference to the literature and to comparative refrence slide preparations. A complete analysis involving the identification of all pollen grains and other microscopic constituents in the sediment was carried out. Three degrees of accuracy including estimates, determination of frequency classes and counts expressed in percentage was used on two slides (prepared as above) independently, from the same honey. Any pollen of wind-pollinated or nectar-lacking plants were noted separately. Abortive and misshapen pollen grains were counted as far as they could be identified. Spores and honey dew elements were noted separately.

\subsection{Botanical origin and pollen density through microscopical examination}

The extent to which a given honey sample is derived from different plant sources was deduced from the frequencies of the pollens and honeydew elements in it. Honey was considered to have been produced mainly from one plant (unifloral honey) if the pollen of that plant is predominant. Honey was regarded honey dew only if ratio of HDE/P was equal to or greater than 3 . Pollen reference slides were prepared.

\subsection{Presentation of frequencies}

500 pollen grains were counted for the determination of relative frequencies .Magnification of 400 to $1000 \mathrm{X}$ was used for identifying the various elements in the sediment. The Identification and counting of pollen grains is done in groups of 100, following 5 parallel equidistant lines uniformly distributed from one edge of the cover slip (22X22mm) to the other, until 500 grains are counted. Abortive, irregular or broken pollen grains are counted if they can be identified. Non-identifiable, nonidentified grains, honeydew elements (HDE), i.e. fungal spores, hyphae and microscopic algae were noted separately. Pollen grain frequencies were estimated according to the following terms: "Very frequent" for grains constituting more than $45 \%$ of the total; "Frequent" for grains constituting 16-45\% of the total; "Rare" for grains constituting 3-15\% of the total and "Sporadic", for grains constituting less than $3 \%$. The frequency classes were described as follows: "Predominant pollen" (more than $45 \%$ of the pollen grains counted); "Secondary pollen" (16-45\%); "Important minor pollen" (3-15\%) and "Minor pollen", (less than 3\%). Honey with predominat pollen type was classified as Monofloral honey. For pollen grains that were not identified as far as the genus or species, a note was added after the scientific name, to indicate that the term was used in a wider meaning. The proportion of the HDE to the total frequency of pollen grains from nectar plants were described as follows: Practically none (0.00-0.09); Few (0.10$1.49)$, Medium quantity (1.50-2.99), numerous (3.00-4.49), Very numerous (>4.50). Estimates of the frequency of pollen grains of anemophilous and other nectar less plants were expressed as follows: "sporadic" (less than 3\% of the total); "rare" (3-15\%) ;"frequent" (16-45\%); "Very frequent" more than 45\%. The identification of pollen types was based on shape, morphological characteristics and size of the pollen grains. Pollen types identified by using reference pollen slides. Acetolysed anther material according to Erdtman (1960), from Eastern Mau apiflora observed in intial studies were used to develop reference slides. Fresh material from Musaceae and Lauraceae were only warmed with 2-5\% KOH solution for 2 minutes instead of acetolysis and their slides sealed with paraffin wax.

\section{RESULTS}

Table1. Mean Pollen density (Log) of honey samples in different months of honey sample collection

\begin{tabular}{llllll}
\hline Month & $\mathrm{N}$ & Mean & Std. Deviation & Minimum & Maximum \\
\hline April & 9 & 5.07 & 0.10 & 4.96 & 5.21 \\
August & 9 & 4.99 & 0.10 & 4.89 & 5.13 \\
December & 9 & 4.81 & 0.09 & 4.68 & 4.90 \\
Total & 27 & 4.96 & 0.15 & 4.68 & 5.21 \\
\hline
\end{tabular}

* The mean difference is significant at 0.05 level.

Pollen counts ranging from 47,898-160,200 were recorded in this study.59.3\%and $40.7 \%$ of honey samples falling in to classes II and III respectively with no representations of Classes I, IV and V. The mean pollen density was highest in April. 
Table 2. Tukeys HSD Post-hoc Multiple comparison of pollen density(Log) between honey samples collected in different months from Eastern Mau forest.

\begin{tabular}{llllllll}
\hline Statistic & (I) Season & (J) Season & $\begin{array}{l}\text { (I-J) } \\
\text { difference }\end{array}$ & Mean & Sig. & \multicolumn{2}{l}{$95 \%$ Confidence interval } \\
Tukey HSD & April & August & 0.08 & 0.19 & -0.03 & 0.19 \\
& April & December & $0.27^{*}$ & 0.00 & 0.15 & 0.37 \\
& August & April & -0.08 & 0.19 & -0.19 & 0.03 \\
& August & December & $0.19^{*}$ & 0.00 & 0.07 & 0.30 \\
& December & April & $-0.27^{*}$ & 0.00 & -0.37 & -0.15 \\
& December & August & $-0.19^{*}$ & 0.09 & -0.30 & -0.72 \\
\hline
\end{tabular}

* The mean difference is significant at 0.05 level.

There was significant variation in the mean pollen density between samples. The significant variation arose between April and December samples, and August and December honey samples.

Table 3. Tukeys HSD Post-hoc Multiple comparison ofpollen density between honey samples collected from different mesoregions of Eastern mau forest.

\begin{tabular}{lllllll}
\hline Statistic & $(\mathrm{I})$ & $(\mathrm{J})$ & $(\mathrm{I}-\mathrm{J})$ & Mean & Sig. & \multicolumn{2}{l}{ 95\% Confidence interval } \\
& Mesoregion & Mesoregion & difference & & & -0.06 \\
\hline Tukey HSD & Kapkembu & Mariashoni & $-0.20^{*}$ & 0.05 & -0.35 & 0.08 \\
& Kapkembu & Nessuit & -0.07 & 0.49 & -0.21 & 0.28 \\
& Mariashoni & Nessuit & 0.14 & 0.07 & -0.01 & 0.35 \\
& Mariashoni & Kapkembu & $0.20^{*}$ & 0.05 & 0.06 & 0.01 \\
& Nessuit & Mariashoni & -0.14 & 0.07 & -0.28 & 0.21
\end{tabular}

* The mean difference is significant at 0.05 level.

There was a significant variation beween the pollen density of honey samples collected from various mesoregions. The variation was contributed by honey samples collected from Mariashoni and Kapkembu.

Table 4. Pollen frequency classes in honey samples collected in Eastern Mau.

\begin{tabular}{|c|c|c|c|c|}
\hline Sample & $\begin{array}{l}\text { Predominant } \\
\text { pollen }\end{array}$ & Secondary pollen & Important minor pollen & Minor pollen \\
\hline$\underline{\text { KA-S1-AP }}$ & & $\begin{array}{l}\frac{\text { Vernonia uriculifera }}{(18 \%), \text { Cordia }} \\
\frac{\text { abyssinica } 17.50 \%),}{\text { Acacia } \operatorname{spp}(33.6 \%) .} \\
\text { Albizia coriaria }(20 \%)\end{array}$ & $\begin{array}{l}\text { Eucalyptus spp.(4.70\%), Grevillea } \\
\text { robusta }(3.90 \%),\end{array}$ & $\begin{array}{l}\text { Asystasia gangetica }(0.50 \%), \text { Achyranthes } \\
\text { aspera }(0.10 \%), \text { Malvaviscus arboreus }(0.10 \%), \\
\text { Moringa Oleifera }(0.10 \%), \text { Prunus africana } \\
\underline{(0.40 \%), \text { Cissus rotundiflora }(0.90 \%)}\end{array}$ \\
\hline$\underline{\mathrm{KA}-\mathrm{S} 2-\mathrm{AP}}$ & & 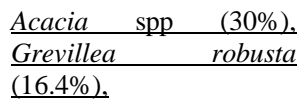 & $\begin{array}{l}\text { Cordia abyssinica }(15 \%), \quad \text { Albizia } \\
\underline{\text { coriaria }(14 \%), \text { Achyranthes aspera }} \\
\underline{(5 \%)}\end{array}$ & $\begin{array}{l}\text { Achyranthes aspera }(5.0 \%), \text { Sida acuta }(0.8 \%), \\
\text { Melia azedarach }(0.60 \%), \text { Lantana camara } \\
\underline{0.60 \%)}\end{array}$ \\
\hline KA-S3-AP & & $\begin{array}{l}\frac{\text { Vernonia uriculifera }}{(24.10 \%), \text { Acacia spp }} \\
\frac{(36 \%), \text { Psidium Guajava }}{(17 \%),}\end{array}$ & Eucalyptus spp.(13.50\%), & $\begin{array}{l}\text { Achyranthes aspera }(2.40 \%), \text { Moringa Oleifera } \\
\begin{array}{l}\text { europaea ssp Africana }(0.70 \%), \text { Pinus type } \\
\text { eurinen }(0.70 \%), \text { Grevillea robusta }(2.80 \%), \text { Prunus }\end{array} \\
\text { africana }(0.60 \%), \text { Lantana camara }(0.80 \%)\end{array}$ \\
\hline
\end{tabular}


International Journal of Advances in Scientific Research and Engineering (ijasre), Vol 5 (7), July-2019

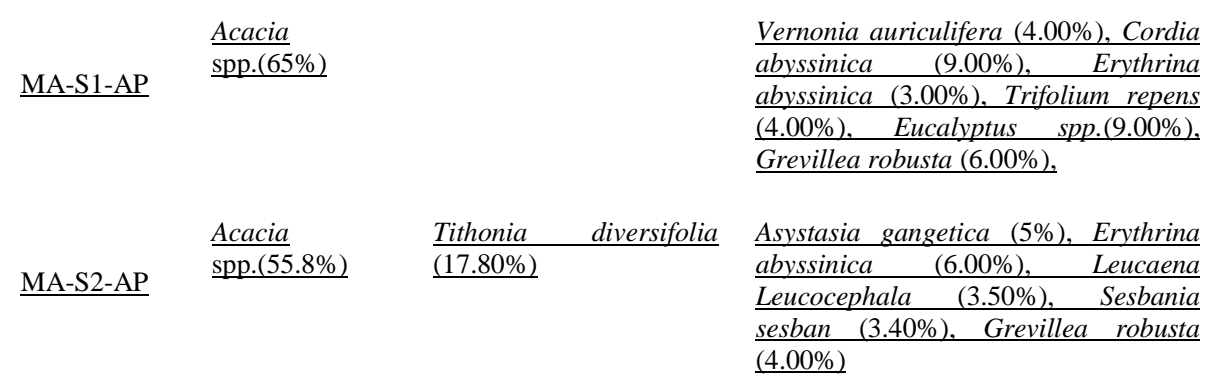

Eucalyptus spp. $(56.50 \%)$

$\underline{\text { MA-S3-AP }}$

NE-S2-AP

NE-S3-AP

$\underline{\mathrm{KA}-\mathrm{S} 1-\mathrm{AU}}$

Albizia coriaria (47.10\%)

Croton

spp. $(60 \%)$

NE-S1-AP

(1)

Aspilia mossambicensis (16.8\%)
Acacia spp.(24.00\%)

\begin{tabular}{lr} 
Albizia & coriaria \\
\hline$(19.50 \%)$, & Leucaena \\
\hline Leucocephala & $(17.80 \%)$, \\
\hline Tamaridus & indica \\
\hline$(18.00 \%)$ &
\end{tabular}

Vernonia auriculifera (3.40\%), Cordia abyssinica (4.10\%), Acacia spp.(3.40\%), Albizia coriaria (6.00\%), Erythrina abyssinica (7.00\%),

Achyranthes aspera (3.7\%), Cordia abyssinica $\quad(4.10 \%), \quad$ Acacia spp.(5.90\%), Glircidia sepium (4.00\%), Trifolium repens $(3.50 \%)$

Vernonia auriculifera $(9.60 \%)$, Cordia \begin{tabular}{lll} 
abyssinica $\quad(10.70 \%), \quad$ Croton \\
\hline
\end{tabular} spp.(11.10\%), Grevillea robusta $\underline{(9.90 \%)}$

Cordia abyssinica (10.50\%), Albizia coriaria (11.00\%), Sesbania sesban (13.00\%), Trifolium repens $(8.70 \%)$

Sesbania sesban (8.20\%)

\begin{tabular}{lr} 
Mangifera & indica \\
\hline$(17.4 \%)$, & Terminalia
\end{tabular} brownii (23.00\%), Croton spp.(16.30\%)

Cordia

$\underline{\text { KA-S2-AU }}$ abyssinica $\underline{(56 \%)}$

$\underline{\text { KA-S3-AU }}$

$\underline{\text { MA-S2-AU }}$

Croton

spp. $(50.20 \%)$

MA-S1-AU

MA-S3-AU

Odontonema strictum (0.6\%), Achyranthes aspera $(0.5 \%)$ Aloe secundiflora $(0.3 \%)$, Terminalia brownii $(0.40 \%)$, Ipomoea batatas $(0.2 \%)$, Euphorbia hirta (0.60\%), Tamaridus indica $(0.30 \%)$, Zea mays $(0.70 \%)$,

Achyranthes aspera (0.7\%), Rhus nataliensis $(0.6 \%)$ Vernonia auriculifera (0.60\%),Terminalia brownii (0.30\%), Euphorbia hirta $(0.40 \%)$, Cynodon dactylon $(0.20 \%)$, Zea mays $(0.30 \%)$, Grewia bicolor $(1.40 \%)$

Odontonema strictum $(0.30 \%)$, Aloe secundiflora $(0.40 \%)$, Leucaena Leucocephala $(0.30 \%)$, Tamaridus indica $(0.40 \%)$, Cynodon dactylon (0.30\%), Sorghum bicolor $(0.50 \%)$, Prunus africana (0.40\%), Grewia bicolor $(0.20 \%)$

Vernonia auriculifera $(0.60 \%), \quad$ Terminalia brownii $(0.60 \%)$, Ipomoea batatas $(0.40 \%)$. Callistemon citrinus $(0.90 \%)$, Olea europaea $\underline{(0.60 \%)}$

Asystasia gangetica (0.5\%), Odontonema strictum $(0.7 \%)$, Achyranthes aspera $(0.3 \%)$, Sida acuta (1.30\%), Lantana camara $(0.60 \%)$

Odontonema strictum (2.6\%), Achyranthes aspera $(2.6 \%)$, Ipomoea batatas $(0.90 \%)$, Tamaridus indica $(0.60 \%), \quad$ Malvaviscus arboreus (0.80\%), Eucalyptus spp. (2.30\%)

Acacia spp. $(0.50 \%)$, Asystasia gangetica $(0.6 \%)$ Polyscias fulva (0.3\%), Bothriocline fusca (2.00\%), Hellianthus Annuus $(2.90 \%)$, Jacaranda mimosifolia (2.70\%), Maerua triphylla (0.30\%), Carica papaya $(1.70 \%)$

Justicia exigua (6\%), Rhus nataliensis (3.8\%), Combretum molle (8.00\%), Albizia coriaria (4.30\%)

Asystasia gangetica (0.6\%), Pupalia lappacea $(0.3 \%)$, Aloe secundiflora $(0.7 \%)$, Opuntia ficusindica $(0.70 \%)$, Carica papaya (0.20\%), Croton spp. $(0.60 \%)$, Glircidia sepium $(0.20 \%)$

Mangifera indica Justicia flava (7\%), Cordia abyssinica (27.00\%), Vernonia (13\%), Croton spp.(10.00\%), Albizia auriculifera $(34 \%)$ coriaria $(4.50 \%)$

Odontonema strictum (0.5\%), Achyranthes aspera $(0.7 \%)$, Aloe secundiflora $(0.3 \%)$, Aspilia mossambicensis $(2.10 \%)$, Carica papaya $\underline{(0.50 \%), \text { Lantana camara }(0.40 \%)}$

Mangifera indica (4.00\%), Vernonia auriculifera (12.60\%), Cordia abyssinica ( $8.30 \%)$, Acacia spp.(14.00\%)

Justicia flava (0.70\%), Mormadica foetida (0.40\%), Persea americana (2.90\%), Trifolium repens $(3.00 \%)$, Psidium Guajava $(2.70 \%)$, Citrus limon (0.50\%), Lantana camara $(0.70 \%)$

Aspilia mossambicensis (0.50\%), Tithonia diversifolia $(2.80 \%)$, Combretum molle $(0.60 \%)$ Leucaena Leucocephala (2.70\%), Psidium Guajava $(0.70 \%)$, Lantana camara $(0.80 \%)$

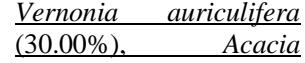
spp. $(29.00 \%)$

Cordia abyssinica
$\frac{(30.00 \%), \quad \text { Albizia }}{\text { coriaria }(28.50 \%)}$

Mangifera indica (14.50\%), Mimosa invisa (14.80\%), Trifolium repens (3.60\%)

Mangifera indica (8\%), Vernonia auriculifera (14.5\%), Acacia spp. $(7.7 \%)$
Justicia flava $(0.70 \%)$, Achyranthes aspera (0.6\%), Tithonia diversifolia (2.80\%), Ipomoea batatas $(0.40 \%)$, Crotalaria brevidens $(0.30 \%)$, Delonix regia (2.70\%), Tylosema spp. $(0.80 \%)$ Ocimum gratissimum (2.30\%), Lantana camara $(0.70 \%)$ 
International Journal of Advances in Scientific Research and Engineering (ijasre), Vol 5 (7), July-2019

Dombeya torrida (43\%), Mangifera indica (28\%)

Hellianthus Annus (7.00\%), Cordia abyssinica $(13.00 \%)$

NE-S1-AU

NE-S2-AU

NE-S3-AU

Croton Acacia spp.(28.80\%),

KA-S1-DE

spp. $(66.40 \%)$

KA-S2-DE

$\underline{\text { KA-S3-DE }}$

Vernonia

auriculifera

MA-S1-DE (46\%),Croton

$\underline{\text { spp. }(47.50 \%)}$

MA-S2-DE

MA-S3-DE

NE-S1-DE

NE-S2-DE

Leucas deflexa $(19.00 \%)$

Acacia spp.(27.10\%),

Acacia spp. $26.00 \%)$ Eucalyptus spp.(22.60\%) triphylla $(0.90 \%)$, Mimosa invisa (9.00\%), Morus mesozygia (10.00\%), Passiflora edulis $(0.80 \%)$, Dombeya torrida $(11.00 \%)$

Mangifera indica (13.4\%), Cordia abyssinica $\quad(12.00 \%), \quad$ Acacia spp. $(9.20 \%), \quad$ Trifolium repens (14.00\%), Dombeya torrida (13.00\%) $(0.60 \%)$, Aspilia mossambicensis $(2.00 \%)$ Hellianthus Annus (2.80\%), Jacaranda mimosifolia $(0.80 \%)$, Carica papaya $(0.30 \%)$. Ipomoea batatas $(0.60 \%)$

Agave sisaliana (0.4\%), Pupalia lappacea $(0.7 \%)$. Bothriocline fusca $(0.60 \%)$, Cynodon dactylon $(0.30 \%)$ Malvaviscus arboreus $(0.40 \%)$, Eucalyptus spp.(0.80\%), Dombeya torrida $(0.60 \%)$, Tribulis terrestris $(0.50 \%)$

Aloe secundiflora (0.60\%), Bothriocline fusca $(0.70 \%)$, Leucas deflexa $(0.50 \%)$, Zizyphus mucronata $(0.30 \%)$ Leucocephala (14.50\%), Tephrosia vogelii $(14.10 \%), \quad$ Eucalyptus spp.(13.80\%), Teclea nobilis (14.80\%) spp.(20.00\%), Mimosa invisa (11.50\%)

Aloe secundiflora (2.50\%), Bothriocline fusca $(0.80 \%)$, Phaseolus vulgaris $(1.70 \%)$ Eucalyptus spp.(2.00\%), Zizyphus mucronate (0.70\%),Trema orientalis $(0.60 \%)$

Acacia spp.(1.30\%), Ocimum gratissimum $(0.50 \%)$, Grewia bicolor $(0.50 \%)$, Trema orientalis $(0.70 \%)$

Agave sisaliana (1.4\%), Aloe secundiflor (1.20\%), Combretum molle ( $0.90 \%)$

Bothriocline (38\%) diversifolia $(40 \%)$

Acacia spp. $(36.10 \%)$ Eucalyptus spp.(27.40\%)

Acacia spp.(43.00\%)

Combretum molle (31.00\%), Acacia spp.(35\%), Leucaena Leucocephala $(31.40 \%)$
Leucaena Leucocephala (13.50\%), Mimosa invisa $(1.80 \%), \quad$ Tylosema spp. $(0.50 \%), \quad$ Persea americana $(0.30 \%)$, Melia azedarach $(1.40 \%)$

Vernonia auriculifera (9\%), Combretum molle (13.00\%), Croton spp.(11.00\%)

Vernonia auriculifera (14.50\%) Cordia abyssinica (13.80\%) Combretum molle (13.20\%), Mimosa invisa $(13.50 \%)$
Agave sisaliana (2.1\%), Aloe secundiflora $(0.70 \%)$, Combretum molle $(1.7 \%)$

Mimosa invisa (2.10\%), Melia azedarach (1.20\%), Pinus type( $(0.20 \%)$

Justicia exigua ( $0.6 \%)$, Agave sisaliana ( $0.8 \%)$ Aloe secundiflora $(0.30 \%)$, Tephrosia vogeli $(0.60 \%)$, Pennisitem purpureum $(0.20 \%)$, Leucas deflexa $(0.10 \%)$

Agave sisaliana $(0.6 \%)$, Polyscias fulva $(0.7 \%)$ Aspilia mossambicensis $(0.40 \%)$, Eriobotrya japonica $(0.30 \%)$ 
International Journal of Advances in Scientific Research and Engineering (ijasre), Vol 5 (7), July-2019 $\frac{\text { Vernonia auriculifera }}{(43 \%), \text { Combretum molle }} \quad$ Croton spp.(13.10\%) $\underline{(40.00 \%)}$
Cucurbita pepo $(0.20 \%)$, Agave sisaliana $(0.50 \%)$, Aloe secundiflora $(0.70 \%)$ Pentaclethra macrophylla $(0.60 \%)$, Phaseolus vulgaris $(0.40 \%)$, Pennisitem purpureum (0.40\%), Malvaviscus arboreus $(0.80 \%)$, Musa acuminata $(0.30 \%)$

8 monofloral honey samples were observed. Five honey samples lacked the secondary pollen types. Unifloral honey samples were observed from the three mesoregions of Eastern Mau forest. 50\% of the unifloral honey were collected in April (2016). Botanical origin from predominant pollen types were Acacia spp type, Eucalyptus type, Croton spp. type, Albizia coriaria type, Cordia abyssinica type, and Vernonia auriculifera type. The extent of predominance ranged from (47.1\%-66.40\%), there was bifloral honey observed in MA-S1-DE sample (Vernonia auriculifera type and Croton spp. type , $46.0 \%$ and $47.50 \%$ respectively). Secondary pollen ranged from (16.4\%-43.4\%). All honey samples were floral honey. $29.63 \%$ were unifloral honey while therest were multifloral/heterofloral honey. Unifloral honey was observed from the three mesoregions of Eastern Mau forest.50\% of the unifloral honey were collected in April during the main bloom, 37.5\% in August, and 12.5\% in December. 50\% of the samples were collected from Mariashoni(April-3, August-1), 37.5\% from Kapkembu (August-2 and December-1), and 12.5\% from Nessuit (April). Apart from Predominant pollen type there were secondary pollen ,important minor or minor pollen. Secondary pollen ranged from $(16.4 \%-43.4 \%)$,

\section{DISCUSSION}

The quantity of pollen in a given honey sample of honey gives a clue to determining its purity and genuineness. Pollen counts of honey samples in this study indicate that the honey samples were undiluted (Agwu et al, 2013). The more the pollen content, the more the preference for nectar from these plants attributeable to their sweet nectar to the honey bees (Ige and Apo, 2007). High pollen content also reflects richness of pollen grains and abundance of polleniferous species (Laura and Cynthia Fernandes, 2018). Higher pollen density in forested areas Thiruvananthapuram district have been reported by (Aswini , 2013) citing Nair (2005). The variation in pollen density between the locations and locations within the seasons may be attributed to the diversity and richness of bee flora in different locations as well as bee forage preference of bees within various locations (Aswini , 2013), an argument that has been supported by other studies (Bhargava et al. 2009; Shubharani et al. 2012 ).

During dearth season, the lowest mean pollen density have been recorded (Aswini , 2013), however, increased pollen density during dearth season in upland indicates either heightened foraging activity of bees in upland than in midland or variation in raining time between sites under study. Such variations could also be attributed to differences in floral diversity and foraging activity of honey bees revealing the influence of climate (Aswini , 2013).

brood rearing season have coincided with Honey samples rich in maximum mean pollen density across sites, while the dearth season record lowest mean pollen density (Sadia et al., 2008; Nair, 2005). This is expected since pollen is a significant ingredient for bee nutrition, brood development and for maintenance of a healthy bee colony and a source of proteins, amino acids, carbohydrates, vitamins and hormones. In order to meet the dietary requirements of the brood, foraging bees will collect ample quantity of pollen which results in higher pollen density during brood rearing season. The importance of pollen as major source of protein to the brood has been also reported from the studies conducted by Sadia et al. (2008). APC ranging from 908 to 62844/gm higher than our results have been reported (Boudilio et al., 2002). Extreme values of 7055 to 546,558/10g (Ana and Francisco, 2014) and 19,388 to 950,347 reported by Novais (2013). While studying the honey pollen in Delta state, Igbe and Obasanmi (2014) recorded pollen counts ranging from 10,409 to 712,634, while pollen grain counts ranged from 532 to 1033 , (Agwu et al., 2013).

Honey samples studied by (Novais, 2013; Alicia, 2008; Ana and Francisco, 2014) as in this study, also never fell in class V. There are no consistent classes that honey samples fall. This is in consort with the findings of most honey samples being categorised as falling in Class II, (Novais, 2013), III (32.3\%) and IV (35.3\%), Laura and Cynthia Fernandes, (2018) and I (23.8\%) and II $(61.9 \%)$ by Ana and Francisco, (2014). Honew dew elements in this study represented shreds of fungal hyphae and fungal spores such as uredospores of Puccinia, Conidia of Fusarium sp, though in very limited proportions. The HDE/P ratio ranged from 0.001-0.05 and thus the honey dew elements were insignificant as per (Louveaux, 1978). Similar results have been reported by Samir et al. (2007). In contrast, 62\% of honey samples with values between 16-2067 were reported by Boudilio et al., (2002). HDE values depend on the procedure for honey extraction. Honey harvested by decanting had a higher pollen density than the ones centrifuged. Boudilio et al. (2002) suggested that low HDE index indicates that flowers make the main source of honey from the region (Louveax, 1978).

Most of the minor pollen taxa types were herbaceous or members of the graminacious types. The predominant and secondary pollen types were mainly from trees and shrubs. The contribution of pollen types were coinciding much with their bloom. More unifloral honeys than multifloral honeys have been reported by (Ana and Francisco, 2014; Baudilio et al. 2002; Rasic et al , 2018). While other studies (Alicia, 2008; Ashoke , 2014; Sunita and Mattu, 2018) more mutlifloral than unifloral honeys were recorded. Eastern Mau complex endowed as it is with a rich and varied floristic complex has the natural potential for establishing an organised bee keeping industry for the production of commercial quantities of single source (Unifloral honeys). Frequency classes extracted in this study made it possible to evaluate the periodic contribution of each pollen type to the composition of the pollen spectrum of a sample. Thus predominant pollen types have a high botanical affinity for plant species with a more significant monthly contribution to the composition of a given spectrum. Predominat types were present in a fewer samples than the other frequency classes. The pollen spectrum in a sample isnt sufficient to determine the botanical origin of the honey (Molan , 1998). Because of this reason, one must assume that no honey is completely unifloral and that the amount of pollen and nectar produced 
by plants varies according to different factors linked to seasonality, climate, soil conditions among others. Pollineforous plant species can also contaminate the honey and mask other species subrepresented which could be good nectar suppliers as well as important indicators of the regional provenience of honey (Novais, 2013).

The types/plants that are either predominant or secondary pollen types raise a possibility of producing single source honey on commercial scale (Samir et al., (2007). Honey analysis by Luz et al., (2010) observed Mimosa scabrella, Myrcia type, and Sorocea types as the predominant pollen types. Similarly in our results, only a number of types were predominant. Preferences of floral sources during the major part of the time was demonstrated in spite of the strong anthropic influence. Polliniferous variety, is indicative of the potential for monofloral as well as heterofloral pollen production (Luz et al., 2010).

Although some plants taxa were prominent in the pollen spectrum in terms of their high frequencies in our results, bees tended to continue collecting from minor pollen taxa that provide small amounts of food. Such minor contributors plants become alternative sources of trophic resources for the colony and are particularly useful when other providers of pollen and nectar are saturated by other pollinators or are diminished. Moreover a priori, those secondary or minor sources could over time occupy central position in the food supply (Novais, 2013). While this study recorded 6 pollen types as predominant (at least $45 \%$ ), 13 types (Alicia, 2008), 10 types (Ana and Francisco, 2014) demonstrating variation on extent of predominance in samples of various origin.Trifolium type (Fabaceae) and Eucalyptus type (Myrtaceae) accounted for he monofloral honey. With $31 \%$ of pollen types corresponded to native flora (Alicia , 2008).

Predominant pollen types included Prunus sp., Eucalyptus camaldulensis, and Rutaceous member have been reported by (Sunita and Mattu, 2018), Eucalyptus saligna, Terminalia mantaly, and Parthenium sp (Asteraceae) was recorded as predominant and secondary pollen (Ashoke, 2014). Predominance in pollen contribution could be attributed to widespread presence or spontenous flowering as seen in Parthenium as well Eucalyptus saligna and Terminalia mantaly which were much foraged during the two seasons (Ashoke, 2014). Helianthus type (Asteraceae) have also been reported in Boudilio et al., (2002) as a predominant type. Predominant and important minor pollen were significantly higher in rainy season compared to the dry season in results by Nguemo et al. (2016). Predominance has also been associated by period of abundant flowering (February to November) of the speceis Mikania cordifolia .According to many authors, in periods of high abundance of flowers, Apis mellifera can show high foraging activity in few floral sources. Meanwhile in seasons of reduced availability of floral resources, the bees have to search for resources in a greater number of plant species, which would in turn be reflected in the abundance of pollen types under consideration (Laura and Cynthia , 2018).

Studies by Nguemo et al. (2016) seem to corroborate well with our results as it was observed that during the rainy season, the pollen of Mimosa sp. was dominant and that of Eucalyptus which was not at the blooming peak period during this season, was classified as occasional isolated pollen. The accessory pollen was represented by Eucalyptus sp. Certain predominant pollen type in our study (Eucalyptus type, Acacia, Croton type) were also reported as secondary, important minor and minor pollen in different honey sampled from different sites. Similar trends were reported by Sunita and mattu, (2018). According to Novais, (2013), it is possible that predominat pollen types eg Myrcia (Myrtaceae) from their results, could be from plants which flower throughout the year, but collected only part of the year. It Could be hypothesised that months with low frequency of such pollen types represent flowering periods of alternative or more attractive sources of nectar or pollen for the bees. The predominant types Eg Acacia sp. obserevd in our studies were in bloom for a long period indicating that species related to this pollen type flower throughout much of the year. Such predominat pollen typescould flower with different intensities at different months and their presence also affected by diversity of nectar sources (Mathew et al., 2018). The Secondary pollen types: Erythrina sp., Eucalyptus camaldulensis, Citrus sp., Callistemon citrinus, Psidium guajava, Acacia sp., Terminalia sp., Moringa oleifera, Important minor pollen: Mangifera indica, Eryhthrina sp., Ipomoea sp., Zizyphus sp., Hibiscus sp., and members of Cucurbitaceae, Apocynaceae, Rosaceae, Meliaceae, Poaceae, Euphorbaceae present in different honey samples studied by Sunita and Mattu (2018); Zea mays and Trifolium reported by Cenet et al., (2015) while studying the honey samples of Turkey are in consort with the taxa reported in our studies. Mimosa pudica (Fabaceae) and Zizyphus type (Rhamnaceae) have also been reported by Ana and Francisco (2014) as accessory pollen are in agreement with their obserevd contribution in our results. That Convolvulaceae, Anacardiaceae, Fabaceae and Acanthaceae are also preferred as minor source of pollen and nectar (Aswini , 2013) is in agreement with the present study.

\section{CONCLUSION}

Pollen density varied with seasons. Lowest pollen density was observed in dearth period. Honey classes fell in classes II and III. The honey dew elemens were insignificant in the honey samples. All honey samples were floral honey including , unifloral honey $(29.63 \%)$, and $70.37 \%$ composed of heterofloral honey. Predominnt pollen types were present in fewer samples than the other frequency classes.

\section{REFERENCES}

[1] Alaazi, D. A., Agbenorhevi , M., and Cassandra O. (2010). The honey industry in

Ghana: An overview. Pp 1-52.

[2] Alicia Forcone (2008). Pollen analysis of honey from Chubut (Argentinean Patagonia), Grana, 47:2, 147-158, DOI 10.1080/10652460802106340.

[3] Ana, P. C. S. and Francisco de Assis Ribeiro dos Santos (2014). Pollen diversity in honey from Sergipe, Brazil. 53:2, 159-170. DOI:10.1080/00173134.2014.896941

[4] Agwu, C. O. C., B. C. Essien and S. A. Badmus (2013). Melissopalynological Study of Honey Samples from four localities in Dekina Local Government Area of Kogi State, Nigeria.J. Biol. Chem. Research 30(2): 921-928. 
[5] Ashoke, B. (2014). Melissopalynological study of Nadia District, WEST Bengal, India. International Journal of Current Research 6 (5): pp.6521-6526.

[6] Aswini S. (2013) Melissopalynology of Indian Honey bee (Apis cerana indica) Apiaries in Southern Kerala. Thesis. Kerala Agricultural University. Pp 1-114.

[7] Attri, P. K. 2010. Melissopalynological Studies of Apis cerana Summer honey from Chamba District of the Himachal Pradesh, Assian Journal Experimental Biological Science, (1), 930-939.

[8] Akratanakul, P. 1990. FAO Agricultural Services Bulletin 68/4, Food and Agriculture Organization of the United Nations, Rome.

[9] Barbara, D., and Jürgen, P. (2009). Forest user perceptions of today's forests in Western Kenya. Conference on International Research on Food Security, Natural Re-source Management and Rural Development, University of Hamburg, October 6-8, 2009. Pp 1-4.

[10] Bhargava, H. R., Jyothi, J. V. A., Bhushanam, M. and Surendra, N. S. 2009. Pollen analysis of Apis honey, Karnataka, India. Apiacta. 44(5):14-19.

[11] Boudilio, H., Rosa, M.V., Roberto ,S.M., Valentin, P. (2002). Characterisation of honeys by melissopalynology and statistical analysis. Canadian Journal of plant science. 82:pp7582.DOI:10.4141/P00-187.

[12] Bradbear, N. (2009). Non-wood forest products: Bees and their role in forest livelihoods, Food and Agriculture Organization of the United Nations, Rome. Pp 1-204.

[13] Bryant, V. M. 2001. The R-Values Of Honey: Pollen coefficients, Palynology, (25), 1-28.

[14] Caccavari, M. and Guillermina, A. F (2016). Pollen specetra of honeys from the Middle delta of the Parana River (Argentina)and their environmental relationship. Instituto Nacional de Investigacion y Tecnologia Agraria y Alimentaria (INIA) Pp 1-12. DOI:10.5424/sjar/2010081-1142.

[15] Cenet, M, Bozdogan, A., Sezer, G., Acar, L., Ulukanli, Z. (2017). Antimicrobial activities, pollen diversity and physicochemical properties of natural honey from Southeastern

[16] Chaturvedi, S. K. and Temsunungla. 2008. Melissopalynological studies at Kupza village of Mokokchung District, Nagaland. J. Palynol. 45(2):89-100.

[17] Ciappini , María C; Gatti, María B.; Di Vito,María V.; Gattuso, Susana; Gattuso Martha (2013) Characterization of Different Floral Origins Honey Samples from Santa Fe(Argentine) by Palynological, Physicochemical and Sensory data APIACTA 43 pp 25 - 36 .

[18] Codex Alimentarius (2001). Revised codex standard for honey. Pp 1-8.

[19] COMESA/FDHS 002 (2004). Standards for honey. Pp 1-8. Accessed on https://law.resource.org/pub/com/ibr/comesa.002. On July 4, 2014.

[20] Corvucci,F., L. Nobili, D. Melucci, F.-V. Grillenzoni, The discrimination of honey origin using melissopalynology and Raman spectroscopy techniques coupled with multivariate analysis, Food Chem. 169 (2015) 297-304.

[21] Erdtman, G. (1960). Investigation of honey pollen. The acetolysis method. Svensk Botanisk Tidskrift, (54), 561-564.

[22] Hansard, Nakuru County (2016). County assembly of Nakuru debates. Wednesday, March 9, 2016.Pp 1-9.

[23] Hawkins, J., Griffith, A., Ford, C.R., Allainguillaume, J., Hegarty, M.J., et al. (2015) Using DNA Metabarcoding to Identify the Floral Composition of Honey: A New Tool for Investigating Honey Bee Foraging Preferences. PLoS ONE 10(8):e0134735. doi:10.1371/journal.pone.0134735

[24] Hausser, Y. 2002. A cross-sectoral approach to beekeeping support. Bees for Development Journal, (64), 67.

[25] Igbe O. E. and Obasanmi, O. O. (2014). A Palynological Assessment of Honey Samples from Delta State, Nigeria .American International Journal of Biology. 2 (2):47-59.

[26] Ige, O.E. and K. A. Apo ( 2007). Pollen analysis of honey samples from two vegetation zones in Nigeria.

[27] Kirk W.D.J, Howes FN (2012). Plants for Bees. A guide to the plants that benefit the bees of the British Isles: International Bee Research Association.

[28] Laura, B. and Cynthia, Fernandes, P. (2018). Grana Vol. 57 (1-2):144-157. Pollen analysis of Atlantaic forest honey from the Vale do Ribeira REgion, state of Sao Paulo, Brazil.)

[29] Louveaux, J., A. Maurizio and G. Vorwohl (1978). Methods of melissopalynology. Bee World, 59:139-153

[30] Luís G. Dias, Ana C.A. Veloso,Mara E.B.C. Sousa, Letícia Estevinho, Adelio A.S.C. Machado, Antonio M. Peres (2015). A novel approach for honey pollen profile assessment using an electronic tongue and chemometric tools. Analytica Chimica Acta 900:36-45. DOI:10.1016/j.aca.2015.10.014.

[31] Luz, C. F.P. , Gabriel, L. B.J., Rafael, L.S. E F. and Priscila, R. D.S. (2010). Comparative pollen preferences by africanized honeybees Apis mellifera L. of two colonies in Pará de Minas, Minas Gerais, Brazil.Anais da Academia Brasileira de Ciências 82(2): 293-304.

[32] Mathew Pound, Alice Dalgleish, Jessica McCoy and Jessica Partington (2018). Melissopalynology of honey from Ponteland, UK, shows the role of Brassica napus in supporting honey production in the suburban to rural setting,Palynology (42) 3:pp 400-405, DOI:10.1080/01916122.2017.1362485.

[33] Molan, P. (1998). The limitations of the methods of identifying the floral source of honeys. Bee World 1998, 79, $59-68$.

[34] Nair, M. C. 2005. Palynological identification of resources for development of apiculture in Kerala- A case study. J. Palynol. 41 (1-2): 115-138. 
[35] Nascimento DL, Nascimento FS (2012) Extreme effects of season on the foraging activities and colony productivity of a stingless bee (Melipona asilvai Moure, 1971) in Northeast Brazil. 2012: Article ID 267361, 6 pages. doi:10.1155/2012/267361.

[36] Nguemo, D., Mapongmetsem, P.M. and Abdoulaye, M. (2016). Plants Foraged by Apis mellifera adansonii Latreille in Southern Chad. Open Access Library Journal, 3: e2831. http://dx.doi.org/10.4236/oalib.1102831

[37] Novais, Jailson Santos (2013). Estudos palinologicos de produtos meliponicolas provenientes do Baixo Amazonas e da Caatinga do Nordetes do Brasil. Manaus : [s.n],2013.xxiii, 201 f.il.color.

[38] Ponnuchamy, R., Bonhomme, V., Prasad, S., Das, L., Patel, P.,Cédric, G.,Arunachalam P., Krishnamurthy, A. (2014). Honey Pollen: Using Melissopalynology to Understand Foraging Preferences of Bees in Tropical South India. PLoS ONE 9(7): e101618. doi:10.1371/journal.pone.0101618

[39] Rašić, S., Štefanić, E., Antunović, S., Jović, J., Kristek, S. (2018). Pollen analysis of honey from North East croatia. POLJOPRIVREDA 24(2) 43-49. ISSN: 1848-8080.DOI:10.18047/poljo.24.2.6

[40] Sadia, B., Husain, S. H. and Malik, R. N. 2008. Pollen analysis and heavy metals detection in honey samples from seven selected countries. Pakistan J. Bot. 40 (2): 507-516.

[41] Salonen, A., and Julkunen-Tiito, R. 2012. Characterization of two unique unifloral honeys from the boreal coniferous zone: Lingonberry and mire honeys. Agricultural and Food Science, (21) 159-170.

[42] Samir, K.M., Sudha, G., A.P. Das, Subir, B. (2007). The beekeeping potential of Sub Himalayan West Bengal, India: A palynological assessment of honey.Journal of Apicultural research and Bee world. 46(3): 164-177.

[43] Schweitzer, P., Nombré, I., Aidoo, K. and Boussim, I.J. (2013) Plants Used in Traditional Beekeeping in Burkina Faso.Open Journal of Ecology, 3, 354-358. http://dx.doi.org/10.4236/oje.2013.35040

[44] Shubharani, R., Sivaram, V. and Roopa, P. 2012. Assessment of Honey Plant Resources through Pollen Analysis in Coorg Honeys of Karnataka State. Int. J. Pl. Reproductive Biol. 4(1): 31-39.

[45] Singh N and Chaturvedi SK 2017. Melissopalynological studies of Honey samples from Bastar District,Chhattisgarh. The Int. J. Pl. Repr. Biol. 8(1)37-40.

[46] Stubbs, G. (2011).Market introduction of organic fair-trade honey in the UK and South Africa.African Honey bee, (1), 1-6.

[47] Sunita, S. and Mattu,V. K.(2018). Pollen Analysis of Honey Samples From Hamirpur District, Himachal Pradesh, India.The International Journal of Plant Reproductive 10(2) pp.145-150 .

DOI:10.14787/ijprb.2018 10.2

[48] Wilfredo, V. A, Subido, G., and Tinda-an, R. (2010). Indigenous Peoples, Forests \& REDD +: State of Forests, Policy Environment \& Ways Forward. Tebtebba Foundation, Baguio City, Philippines. Pp 14200.

[49] Wilson, M.B., Spivak, M., Hegeman, A.D., Rendahl, A., and Cohen, J.D. (2013). Metabolomics reveals the origins of antimicrobial plant resins collected by honey bees. PLoS ONE. 8(10):e77512. doi:

10.1371/journal.pone.0077512 PMID: 24204850 